At a meeting early this year of the Royal Society of Arts, Commander Levick gave an account of the 1938 expedition to Newfoundland, and it is clear from his description that the boys enjoyed the experiences and must have gained enormously from them $(J$. Roy. Soc. Arts, 87, 970, Aug. 1939). In recent expeditions a number of boys from secondary schools have been included in the party, and the Astronomer Royal, who was in the chair, pointed out that the public schoolboys and the secondary schoolboys had a great deal to gain from this contact with each other and from collaboration in such an enterprise.

\section{Field Archæology in War Time}

Archiologists nowadays for the most part, having other preoccupations, have ceased investigations in the field. Nevertheless, experience in the last war showed that military operations may bring to light evidence which, when recorded with such note of the conditions of discovery as circumstances permit, may point the way, as happened in the Macedonian campaign of 1915-18, to further and valuablo ficlds for further research in later days of more assured tranquillity. The valuable collection of prehistoric antiquities at Salonica is not only an enduring monument to the devotion to archæological studies and the flair of those archæologists who served in the forces in that theatre of the war, but also, on the cessation of hostilities, it served as the starting-point of a series of investigations in the Macedonian field which have thrown a flood of light on cultural movement in this borderland of prehistoric Greece. Nor should it be allowed to be forgotten that it was directly out of Dr. R. C. Campbell-Thompson's military service in Mesopotamia, which afforded him opportunity for an archæological reconnaissance, that there grew the joint expedition of the British Museum and the University of Pennsylvania to Ur, at first under the direction of the late Dr. H. R. Hall, and later of Sir Leonard Woolley-as a whole, and in its effect on study of the growth of early civilizations, which is still far from being exhausted, one of the most momentous in a long series of discoveries in the history of archæology.

Such opportunities in the field overseas are not likely to recur-indeed it is permissible, without risk of misunderstanding, to hope that they will not. But already on the home front a number of finds, recorded in connexion with A:R.P. and other military or defensive activities, bear witness to the vigilance of local archæologists and their solicitude that any evidence of antiquity brought to light shall not escape record. Among the latest finds reported is a discovery at Canterbury (The Times, Sept. 25), where in excavating a trench at the Simon Langton schools, on the site of the White, or Austin Friars' former buildings, material of considerable archæological interest has been brought to light. A passage, built of chalk blocks and believed to lead to the Cathedral, is stated to have been found at this point about twenty-five years ago. The site is also known to cover extensive Roman remains ; but unfortunately, the need for haste demanded the use of a mechanical excavator and precluded scientific examination of the stratigraphic record. Most of the relics found were of medieval date, and included massive parts of what are believed to be the base of the Friary buildings, a simple medieval copper ring, a sixteenth-century inscribed German jetton, and human bones in no particular order, as well as an undisturbed east-towest Christian burial. The copper ring was six feet below the surface in an early, probably medieval, cemetery. Of still greater archæological interest was the evidence of a Roman kitchen midden, from which were obtained much broken pottery coated with soot, some fragments of Samian ware, and quantities of burnt wood. These finds were associated with a. bed of oyster shells.

\section{Reports of the Australasian Antarctic Expedition}

SLowly the reports upon the extensive collections made in Antarctic seas by Sir Douglas Mawson's Expedition of 1911-14 are being completed and published (1, part $3 ; 2$, part 4 ; 2, part 8 . Sydney : Gov. Printer). Among the zoological contributions are Prof. T. Harvoy Johnston's "Parasitic Infusoria from Macquarie Island" which include ciliates from a lamellibranch and a suctorian from an Asellid crustacean, both of which appear to be new to science; an account of forty species of Pycnogonida, among which Decolopoda is not represented, by Dr. Isabella Gordon; and a description by Prof. G. E. Nicholls of seven genera and twenty-six species of Gammarid Amphipods new to science, in a collection which includes ninety species representative of sixty genera.

\section{Earthquake near Smyrna}

AN earthquake of considerable intensity shook the district around Smyrna on Friday, September 22. In Smyrna itself more than 200 people are reported killed, many more injured and 5,000 are without shelter. In the surrounding district several villages have been almost destroyed. During the remainder of Friday and Saturday, aftershocks have occurred almost continuously, accompanied by underground rumblings. This region of Asia Minor is liable to earthquakes and earth tremors. Smyrna was affected by an earthquake which was destructive also at Aidin and places in the Meander Valley on September 20, 1899, though on that occasion the epicentre was somewhat to the south of the present one, being then near lat. $37 \cdot 5^{\circ} \mathrm{N}$., long. $27 \cdot 5^{\circ} \mathrm{E}$. A destructive earthquake again affected Smyrna on March 31, 1928, the epicentre on that occasion being calculated from the readings of 96 seismograms to have been at lat. $38 \cdot 5^{\circ} \mathrm{N}$., long. $28 \cdot 0^{\circ} \mathrm{E}$., somewhat inland to the east of Smyrna. Further data concerning the present shock will no doubt be somewhat delayed, though it appears to have been sufficiently intense to have affected seismographs throughout the world.

\section{Other Recent Earthquakes}

AN earthquake of moderate intensity was recorded at Kew Observatory on September 15. The $P$ waves started at 23h. $21 \mathrm{~m}$. 42s. G.M.T. on the seismogram 
and the epicentral distance has been calculated to be provisionally $2,690 \mathrm{~km}$. On. September 18 an carthquake was reported as having had its epicentre approximately 50 miles from Vienna. This shock damaged nearly all the buildings in the small village near the epicentre, and two people are reported killed. On September 20 several earth tremors wero experienced in Greece. Early in the day sovero shocks rocked the town of Patras, and much apprehension was caused, though thero appears to have been no resultant damage or loss of life. Shocks were felt also in several parts of the Peloponnesus, including Pyrgos, though here also no damage is reported. Minor tremors are relatively common in Greece, though shocks such as the one of April 22, 1928, which partly destroyed Corinth, are not so frequent. The last severe earthquake in Greece was probably that of July 20,1938 , which did damage at Scala Oropos and adjacent villages.

\section{Protection of Wild Birds}

We understand that the Royal Society for tho Protection of Birds has under consideration the drafting of a Bill to amend and consolidate the existing Acts for the protection of wild birds. Such a measure is highly desirable in viow of the com. plexity of the present laws dealing with wild birds. The general lines upon which now legislation should proceed is indicated by certain resolutions drawn up by representatives of the County Councils Association and of municipal corporations, and referred to in the report for 1938 of the Royal Society for the Protection of Birds: (1) that as the complexity of the existing law had led to difficulties in administration, there was, in the opinion of the Conference, a strong case for consolidation and simplification; (2) that protection should be afforded to all wild birds, their nests and eggs, throughout tho wholo year, with specific exemptions which should bo the subject of further discussion; (3) that meantime the Home Office be asked for its views on the matter.

As earlier attempts have shown, it is no easy matter to draft a Bird Protection Bill which is simple, affords all the protection required, and at the same time avoids the danger of opposition from interested persons who may block its passage through Parliament. But with good will and a willingness to compromise on points not vital to the essential interests of wild birds, it should be possible to draft a Bill which would commend itself to reasonablo opinion and obtain the assent of Parliament. On the other hand, possible compotition between Bills drafted by different bodies, such as for example the Royal Society for the Protection of Birds, the Scottish Society for the Protection of Birds, and perhaps the Home Office, should not be allowed to obscure the need and demand for new and simplified legislation, or, when conditions are more favourable, to delay its speedy passage to the Statute Book.

\section{Value of Fruit Juices}

THE possibility of cessation or restriction of supplies of citrus fruits or other fresh fruit juices from abroad makes some recent work carried out at the Long Ashton Research Station, Bristol, of particular value at the present time (Long Ashton, Ann. Rept. 1938). Canned black currant juice would appear to be of special importance. It has a high content of both vitamin $C$ and iron, and has proved extremely useful in cases of ulceration of the stomach and duodenum or hyperacidity. Similarly, apple juice has been successfully used in the treatment of pink discaso (erythrocdema). Information obtained from Switzerland and Germany supports the view of the medical significance of fruit juices, claims being made that they are of benefit in other diseases such as diabetes, inflammation of the lungs or kidneys. The writer suggests that closer co-operation with the medical profession in England is desirable, in order that the true facts and significance regarding the use of fruit juices should be discovered and the danger of any false claims be avoided.

\section{Ordnance Survey Plans}

Is a paper prepared for the British Association meeting at Dundee, but not delivered, Brigadier A. B. Clough outlined the recommendations of the report of the Committee appointed in May 1935 to consider the revision, scales, styles, etc., of Ordnance Survey maps. The recommendations may be noted even if delay must now ensue in the fulfilment of some. The principal points aro those: (I) that no changes be mado in the scales of existing maps ; (2) that the large. scale maps be rearranged so as to form a single national series instead of thirty-nino separato county series; (3) that the revision of the large-scale plans be a continuous rather than a periodic process; (4) that a new series of maps be introduced on a scale of 1 to 25,000 ; (5) that a grid be superimposed on all Ordnance maps. Several subsidiary and consequential recommendations follow, namely, that all large-scale plans should be square, that each 1 to 2,500 plan should cover 1 square kilometro of country, and that the metre should be the unit of measurement for the grid. It is also suggested that additional contours should be added to the six-inch map, and that the practice of publishing archæological maps should be continued.

\section{Research in Freshwater Biology}

The seventh annual report for the year ending March 31, 1939, shows that the Freshwater Biological Association of the British Empire is flourishing. The director, Dr. E. B. Worthington, in his roview and forecast, states that in last year's roport it was forecast that the year now under review would see the launching of new ventures by the Association, building on the foundation laid down during the previous seven years of the Association's history. Of these now developments, three are of primary importance. First, the investigation of the bacteria of fresh water, financed by the Department of Scientific and Industrial Research, has started and the changes in the bacterial flora of Windermere and other waters have now been followed through nearly a whole annual cycle. Secondly, the investigation of 